\title{
The Trajectory of Biofuel Technological Development in Taiwan
}

\author{
Tsui-Miao Chen ${ }^{1,2}$, Ta-Lung $\mathrm{Lu}^{1} \&$ Mei-Chih $\mathrm{Hu}^{3}$ \\ ${ }^{1}$ Graduate Institute of Technology and Innovation Management, National Chung-Hsing University, Taichung, \\ Taiwan, R.O.C. \\ ${ }^{2}$ Livestock Research Institute, Council of Agricultural, Tainan, Taiwan, R.O.C. \\ ${ }^{3}$ Graduate Institute of Technology Management, National Tsing-Hua University, Hsinchu, Taiwan, R.O.C. \\ Correspondence: Tsui-Miao Chen, Livestock Research Institute, Council of Agricultural, 112, Farm Rd., \\ Hsinhua, Tainan, Taiwan, R.O.C. Tel: 886-6-591-2219. E-mail: tmchen@mail.tlri.gov.tw
}

Received: May 30, 2013 Accepted: July 16, 2013 Online Published: August 15, 2013

doi:10.5539/mas.v7n9p19 URL: http://dx.doi.org/10.5539/mas.v7n9p19

\begin{abstract}
This study sought to reveal the evolving technological interdependence of the emerging Taiwanese biofuel industry by accessing the European Patent Office database using a two-stage interactive data collection method. Our empirical results were as follows. (1) Most of the Taiwanese patent rights related to biofuel technologies are held by foreign direct investment (FDI) with a focus on chemical engineering and process technology. (2) Most domestic Taiwanese biofuel technology patents are related to waste management, sludge treatment, and the isolation of micro-organisms. (3) Biofuel is an interdisciplinary technology. Based on the electronics, bio and environmental technologies advantages. Taiwan has the niche to development biofuel in second generation technology. This essay provides the resource-lack countries like Taiwan, through trajectory of inventorying the relevance of related industrial technologies which is supplemented by the key technologies, may serves as effective linkage and catalyst in problem-solving to help select alternative potential energy technologies to stimulate the growth of emerging industries and developed their own advantage industrial technologies and building innovation capabilities.
\end{abstract}

Keywords: patent, innovation, biofuel technology, Taiwan

\section{Introduction}

The challenges associated with energy supply security and climate change have led to increased interest in low-carbon energy, energy-efficient technologies and green-energy industries in the worldwide. Biomass accounts for approximately $14 \%$ of the world's overall primary energy consumption, supplying approximately $35 \%$ of the total energy needs in developing countries. Biomass is considered the most widely used renewable energy (IEA, 2012). A lack of natural energy reserves in Taiwan means that $98 \%$ of total energy needs are met by imports, among which fossil fuels accounts for $91.3 \%$. In addition, the growth of total greenhouse gas emissions in Taiwan increased by $98.6 \%$ between 1990 and 2010. According to the International Energy Agency (IEA/OECD), total carbon dioxide emissions in Taiwan amounted to 270 million tons in 2010, representing approximately 19 metric tons of $\mathrm{CO}_{2}$ per capita (the highest in the world) and $0.89 \%$ of the world's total emissions (Chen \& Chang, 2007). Thus, the development of alternative energy would not only promote energy autonomy but also reduce the carbon footprint of Taiwan.

Technological innovations can play an important role in system innovations, in which the user context, markets or system environment will be largely transformed (Abernathy \& Clark, 1993; Christensen, 2007; Geels, 2005; Wang \& Tang, 2008). In the paradigm of technological innovations, the individual effect of incremental technical change may be only minor might be marginal, whereas the cumulative capacity is essential to construct establish an institutional contexts and innovation infrastructure for the developing development of a nation's innovation system as a whole (Freeman \& Soete, 1997; Dahlin \& Behrens, 2005). For example, technological developments in the chemical industry have been driven by cumulative innovation. The synthetic organics industry based on coal tar has revolutionized dyestuffs and eventually paved the road to plastics, synthetic fibers, biopharmaceuticals, and biofuel. This argument is especially crucial for the technology catching-up countries (e.g. China, Taiwan and Korea) that are accustomed to specialization in demand-pull innovations (e.g. incremental innovations) aimed at the middle or the bottom of the income pyramid. With the hope to leapfrog 
into innovator status and gain international technological supremacy, these latecomers are starting to pursue technology-push innovations (e.g. disruptive innovations), especially in emerging industries such as renewable or biotechnology (Dodgson, Mathews, Kastelle, \& Hu, 2008; Schablitzky, Lichtscheidl, Rauch, \& Hofbauer, 2012).

Technological knowledge serves as a shareable input that is used in research on various technologies and innovations of either sort (Cohen \& Levinthal, 1989; Stolpe, 2002). For example, the current success of biofuel manufacturing is restricted on the one hand by limits on the availability of primary raw materials, and on the other hand by the maturity of fermentation and bio-refinery technologies.

\section{Biofuel Technology in Taiwan}

Biofuel technology in Taiwan includes the production of bio-diesel, bio-ethanol, and bio-gas using waste from municipalities, industrial areas, and wastewater treatment plants. Taiwan was the first country in Asia to widely adopt B2 bio-diesel. However, first generation technology involving the conversion of starch/sugar into fuel was too expensive to compete with imported alcohol products. This led to the development of second generation bio-fuel including the use of lignocelluloses-containing non-food crops or other agricultural waste (such as rice straw) to produce economically competitive cellulosic ethanol. Development is also on-going in other forms of bio-fuels, such as the filtering of oil-rich algae for the production of bio-hydrogen. Recently, biomass torrefaction has been developed to produce electricity from bio-fuel as an alternative to coal. At present, 102 combined-heat-and-power (CHP) plants provide $19.3 \%$ of electrical generation. Biomass torrefaction is estimated to reduce the consumption of coal by approximately one million tons and lower carbon dioxide emissions by 0.24 million tons per year (Industry development Bureau, 2012).

Since 1999, considerable development has gone into refuse-derived fuel (RDF-5), in which urban solid waste is used as a raw material for the production of fuel. Construction of the first RDF-5 manufacturing plant was completed in 2004, with a maximum processing capacity of 24 tons/day. At present, three RDF-5 plants are in operation in Taiwan with a total capacity of 0.18 million tons per year. Most of the methane produced is used as bio-gas power on landfill sites. Bio-gas power facilities for landfill sites in central Taiwan process approximately 2.55 million cubic meters of bio-gas per year, which is equivalent to a reduction of 15,100 tons of methane emissions and the generation of $5448 \mathrm{~kW}$ of electricity, capable of satisfying the energy demands of 7000 families. Table 1 presents the current status and future goals for bio-fuel energy production in Taiwan (Industry development Bureau, 2012).

Table 1. Current status and future targets for biofuel energy in Taiwan

\begin{tabular}{|c|c|c|c|c|c|c|}
\hline \multirow{2}{*}{ item } & \multicolumn{6}{|c|}{ year } \\
\hline & \multicolumn{2}{|c|}{2008} & \multicolumn{2}{|c|}{2010} & \multirow[t]{2}{*}{2015} & \multirow[t]{2}{*}{2020} \\
\hline Electricity & 622.5 & 772 & 622.5 & 841 & & \\
\hline \multirow[t]{2}{*}{$(\mathrm{MW})$} & 24.5 & (total) & 24.5 & (total) & 850 & 1030 \\
\hline & 125 & & 167.5 & & & \\
\hline Biodiesel (kL) & \multicolumn{2}{|c|}{47,000} & \multicolumn{2}{|c|}{$70,000 / \mathrm{B} 2$} & $250,000 / \mathrm{B} 2$ & - \\
\hline Bioethanol (kL) & \multicolumn{2}{|c|}{85} & \multicolumn{2}{|c|}{$159 / \mathrm{E} 3$} & - & - \\
\hline
\end{tabular}

Source: 2012 white book of energy economic industry in Taiwan.

\section{Method}

\subsection{Data Collection and Measurements}

A number of alternative methodologies have been developed for the collection and measurement of technological interdependence and the flow of knowledge. Patents are widely recognized as a reliable and objective indicator of the origins, formation process, and impact of technology (Kortum, 1997). Hu and Phillips (2011) employed a two-stage interactive method using 90 biofuel-related keywords and 95 International Patent Classifications (IPCs) (Appendices A-1 and A-2.) from the Biofpr platform (Biofpr, http://www.biofpr.com) to assemble a comprehensive information platform for biofuel, bioproducts, and information related to biorefining. This paper employed the same 90 keywords, 95 IPCs and the European Patent Office (EPO) database to obtain 
information regarding biofuel-related patents granted in Taiwan. The EPO database covers the domestic and international patenting activities of 128 countries. Intellectual Property Offices have joined as members of the EPO. The commercialization of biofuel technology is not mature yet, only critical patents will be filed internationally, it is useful to examine the international patent families through the EPO worldwide (Webb, Dernis, Harhoff, \& Hoisl, 2005; Harhof, Schererc, \& Vopel, 2003).

\subsection{Measures}

\subsubsection{Technological Interdependence}

To clarify the relationship of technological interdependence between and amongst different technological fields, this study adopts a specific measure of technological overlap, developed by Fung and Chow (2003) to measure the degree of interdependence (DOI) between industries. The formulation is defined as follows:

$$
D O I_{\mathrm{k}, \mathrm{j}, \mathrm{t}}=\frac{T O_{k, j, t}}{P T_{j, t}}
$$

DOI $k, j, t$ denotes the degree of technological overlap between two industries. It is the number of patents simultaneously granted to industries $\mathrm{k}$ and $\mathrm{j}$ at time $\mathrm{t}$; while $\mathrm{PT} j, t$ is the number of patents granted to industry $j$ at time $t$.

\subsubsection{Technological Knowledge Flows}

To capture and reflect faithfully the evolving pattern of development for Taiwan's biofuel innovative capability over the past decades, the empirical results derived from the first stage are then cross verified by analysis of backward and forward patent citations in the EPO to examine its knowledge flows. The dataset is divided into six sectors: (1) universities; (2) public research institutes; (3) state-owned enterprises; (4) private sector; (5) individuals and (6) foreign investor. Backward citation rate refers a count of the citations made reference by a sector's patents to prior patents. This helps to trace the source of innovation/knowledge as well as the developmental trajectory of innovation capability in the sectors (Hu, 2008). On the other hand, forward citation rate represents a count of the citations received by a sector's patents from subsequent patents. This helps to evaluate the technological impact of patents. High citation counts are often associated with important inventions, ones that are fundamental to future inventions and may have more competitive advantages in that technological field.

\section{Empirical Results}

\subsection{Descriptive Statistics}

A total of 16784 patents and 1280 patent families related to biofuel technology were extracted from the EPO database. 92 patents in the field of bio-fuel were published between 1985 to 1994; however, this number began increasing rapidly to 113 in 1995, then declining again after a peak in 2002, as shown in Figure 1. The reason for the decline was the use of food crops such as corn or sugar cane for the generation of bio-fuel, which was believed to negatively affect the food supply and agricultural lands. This, in turn, reduced incentives to pursue $R \& D$ efforts related to the development of bio-fuel technology.

This study also analyzed the top 10 companies that held the most biofuel-related patents, as shown in Figure 2 . These companies included FDI corporations, such as BP, Celanese, BASF, Du Pont, Exxon Chemical and Shell, as well as the Industrial Technology Research Institute (a Taiwan government-funded research institute).

This study employed 3-digit IPC (International Patent Classification) to categorize the biofuel patents in Taiwan (Figure 3). Chemical technology (i.e. C07C, C07B) and processes for the direct conversion of chemical energy into electrical energy (H01M) form the major categories. These results correspond to the present situation in which FDI companies, such as BP, Celanese, BASF and Du Pont, hold the majority of Taiwanese patents in chemical technology. The reason for these corporations filing patents in Taiwan is the development potential of a market importing large quantities of petroleum for processing and the production of plastics, rubber materials, chemical fibers, and other polymers. 


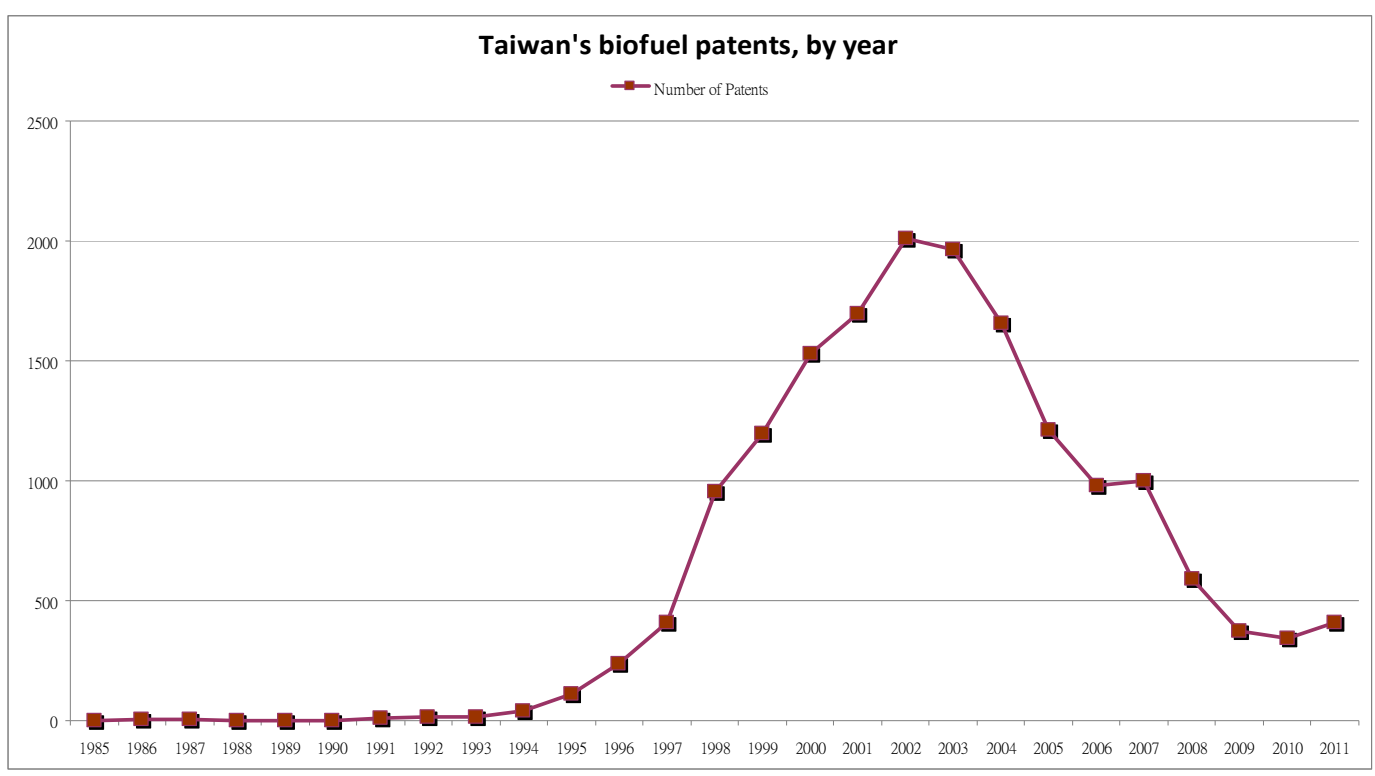

Figure 1. Patents granted for biofuel technologies in Taiwan, 1985-2011

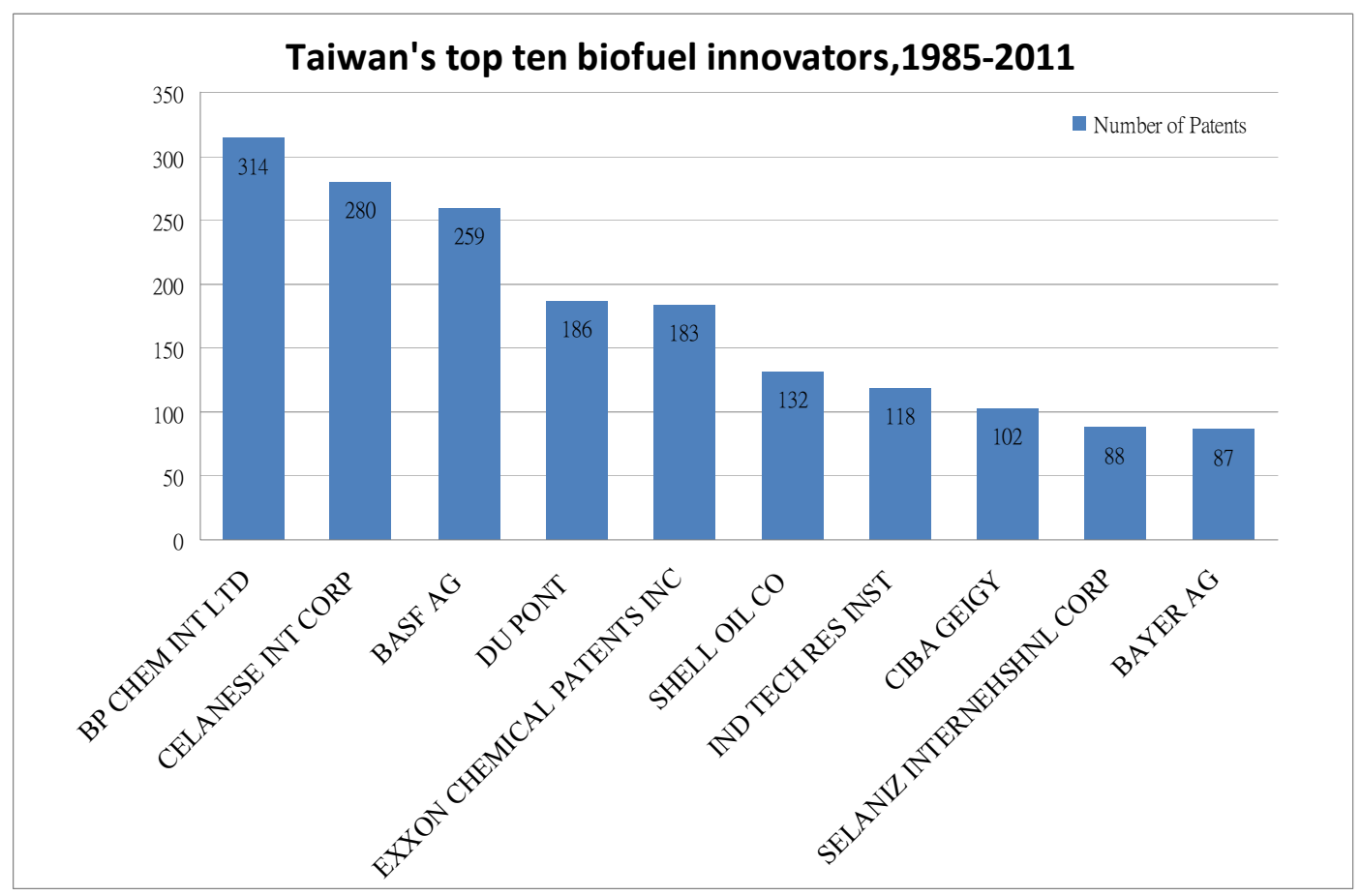

Figure 2. Patents granted to Taiwan's top ten biofuel innovators, 1985-2011 


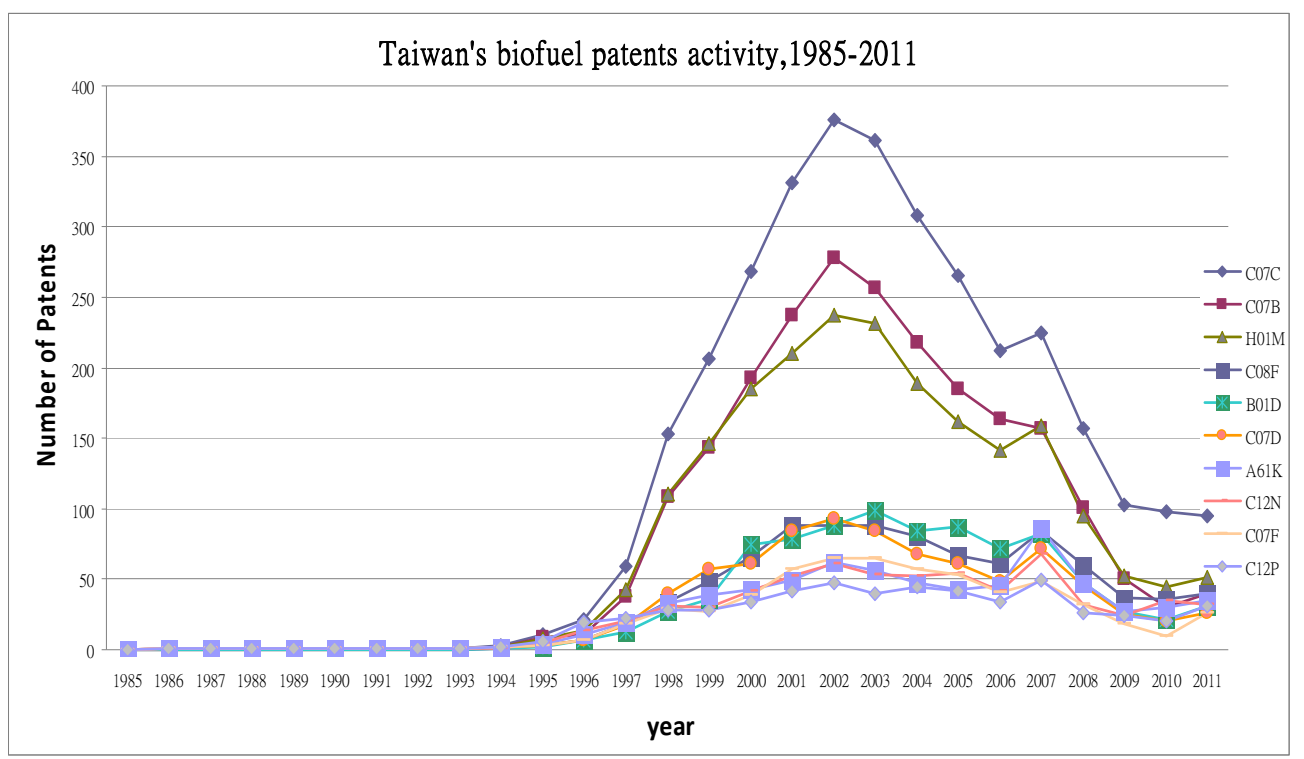

Figure 3. Taiwanese biofuel patents using 3-digit IPC, 1985-2011 (Source: Compiled by the authors from EPO worldwide database)

We then narrowed the patent search to Taiwanese domestic assignees and compared their technological areas. Among the patent assignees, ITRI holds the highest number of 62 patents, in a wider range of patent families than that found in FDI. 39 patents related to biofuel technology are owned by other public research institutes, such as the National Science Council (NSC), the Food Industry Research and Development Institute (FIRDI), and the Development Center for Biotechnology (DCB). Our results are in agreement with those of Wade (2004), indicating that alternative energy technology is largely guided by government policy. Among the top 10 domestic assignees, those belonging to private enterprises included the Asia Pacific Fuel Cell Tech Corp., Chinese Petroleum Crop., Antig Tech. Corp., Nan-Ya Printed Circuit Board., and the Taiwan Semiconductor Manufacturing Company (TSMC) (Figure 4).

The categories of IPC include isolation \& separation (B01D), treatment of solid waste (B09B), treatment of waste water, sewage, and sludge $(\mathrm{C} 02 \mathrm{~F})$, and micro-organisms and enzymes $(\mathrm{C} 12 \mathrm{~N})$ are related to the development of Taiwanese biofuel technology (Figure 5). Clearly, future development will involve the isolation of micro-organisms used in second generation technology. Processes used for the direct conversion of chemicals into electrical energy (H01M) form another important aspect of biofuel technology in Taiwan. TSMC is also listed among the top 10 patent assignees, which shows that the technical expertise of the electronics industry is applicable to the development of biofuel technologies.

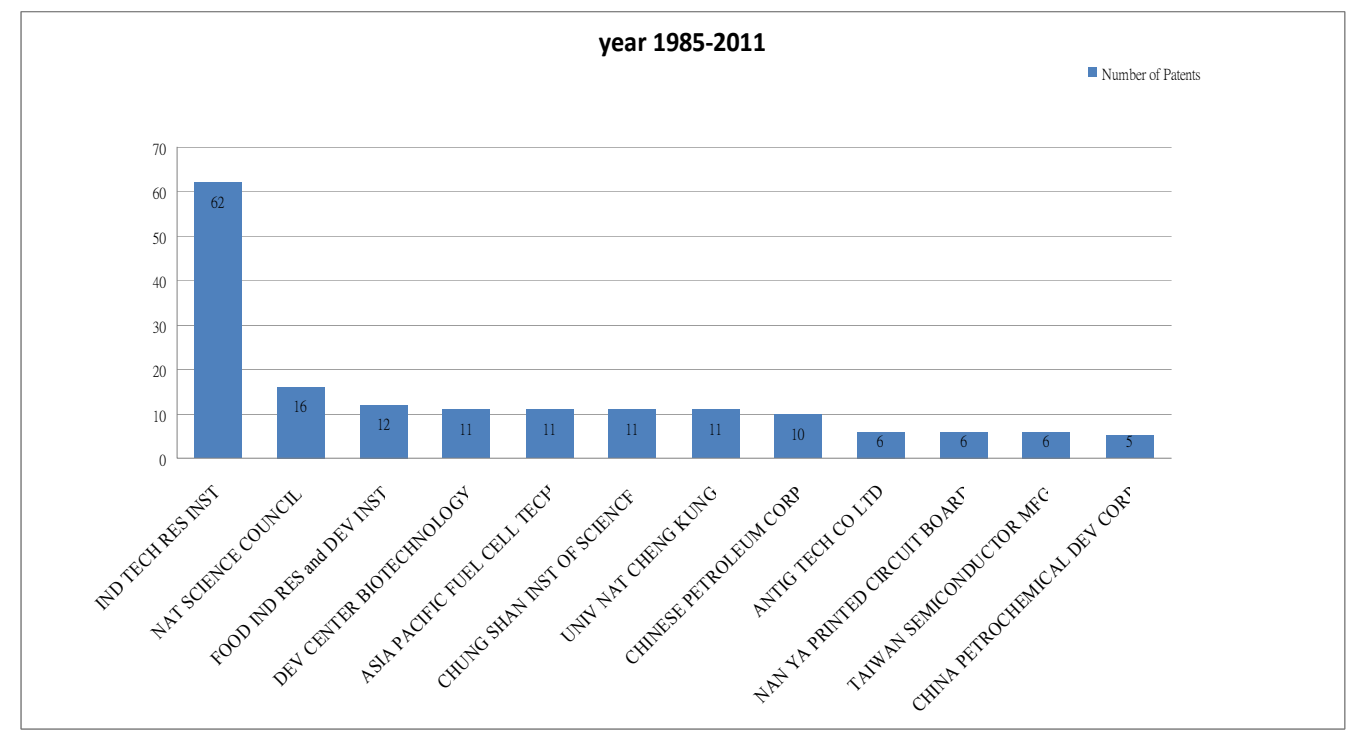

Figure 4. Main players in the domestic Taiwanese biofuel industry, 2000-2011 


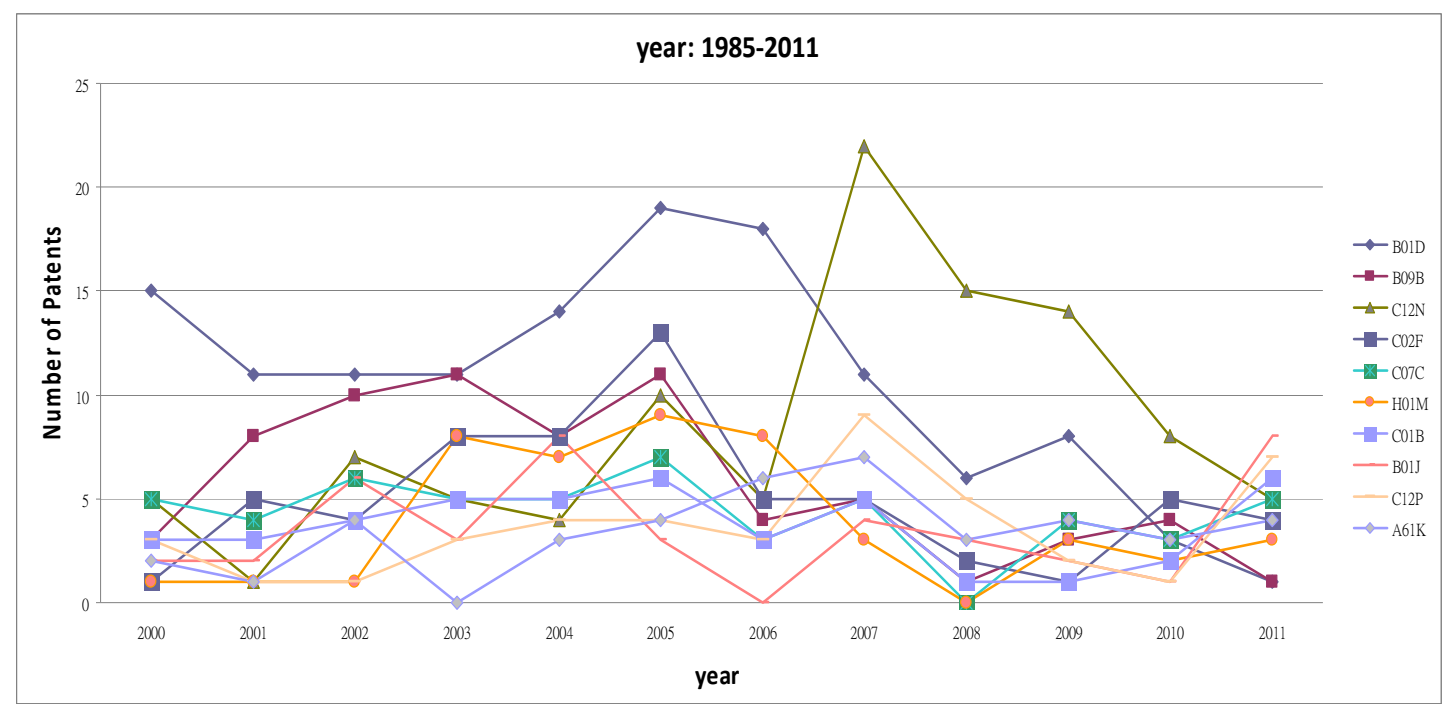

Figure 5. Taiwanese biofuel patent activity obtained using 3-digit IPC (2000-2011)

\subsection{Technological Interdependence}

Patents contain the name of the applicant, filing date, nationality, and a large amount of detailed technical information. Systematic technical classification can help to locate messages such as the technological evolutionary path (Ernst, 2003). This study used patent information to examine the relationship between the dynamic evolution of the Taiwanese biofuel technology and other industrial technologies from 1985 to 2011 . Figure 6 illustratets that the technological dependence on process technology, chemical engineering, and organic chemistry was led primarily by FDI companies. Figure 7 shows that bio-technology and environmental and electrical technology depend more heavily on biofuel technology developed in Taiwan, confirming that biofuel energy technology developed in Taiwan is closely related to technologies associated with the biotechnology and electronics industries.

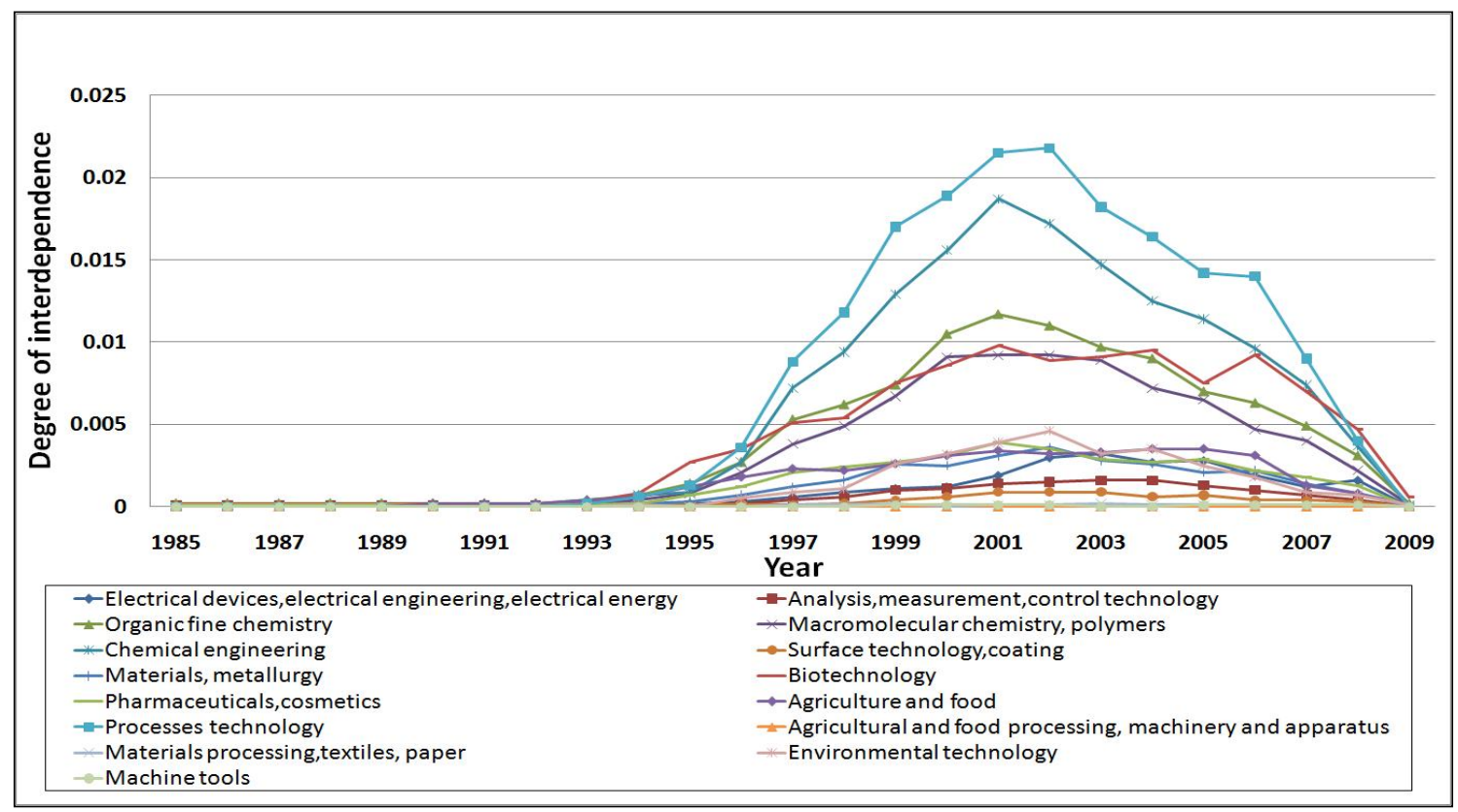

Figure 6. Technological interdependence between biofuel and other industries in Taiwan 


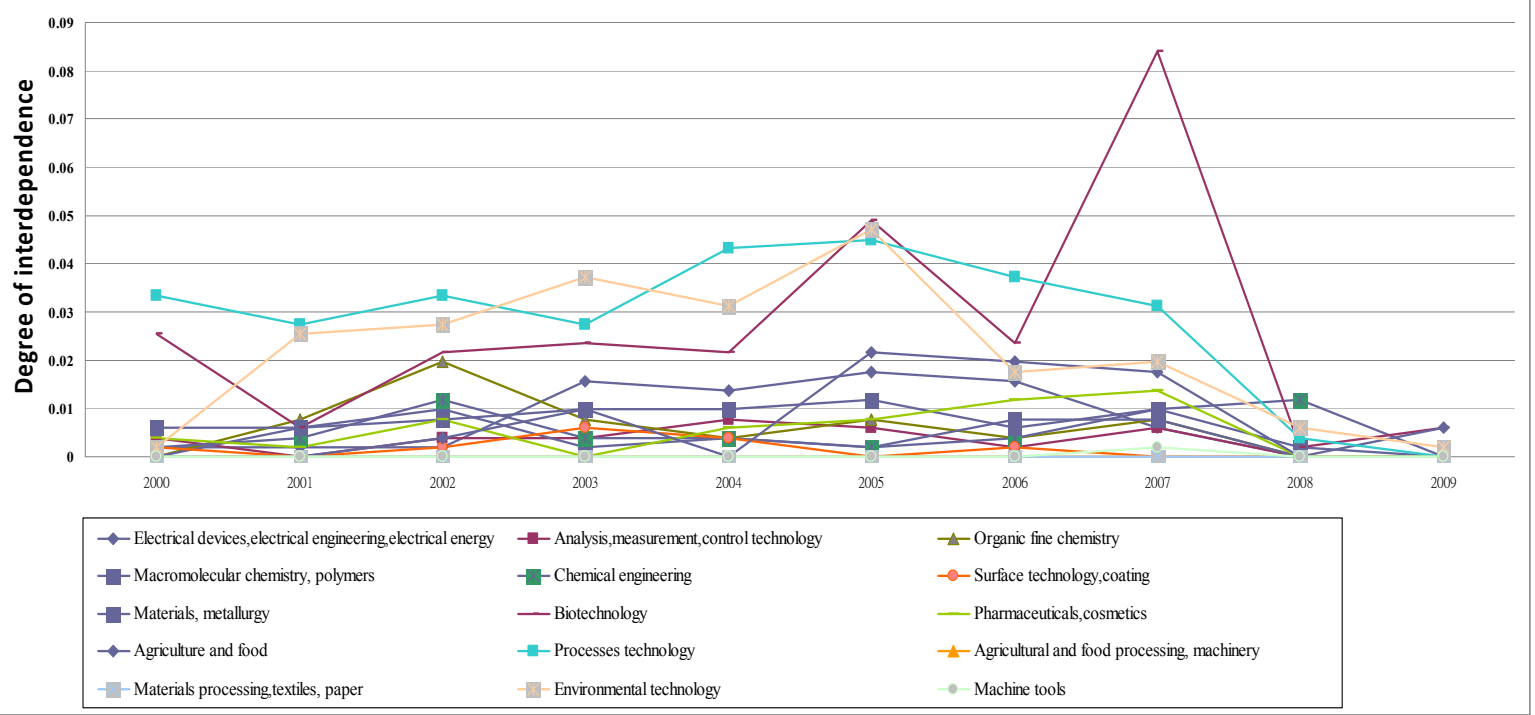

Figure 7. Technological interdependence between biofuel and other industries among domestic Taiwanese assignees

\subsection{Technological Knowledge Flow: Backward and Forward Citation Counts}

This study used patent citations to unravel the flow of knowledge related to Taiwanese biofuel technology. Forward patent citation reflects the actual technical value and influence of a particular patent with regard to follow-up R\&D. Backward patent citation reveals the source of knowledge and the course of technological development related to a particular patent (Cohen \& Levinthal, 1989). Table 2 lists 1080 of the Taiwanese biofuel-related patents held by FDI companies, private individuals, and public research institutes (PRI), which were cited frequently in other countries. Jasjit (2004) claimed that the flow of knowledge in countries receiving investment from FDI companies is generally more conspicuous, due to the state-of-the-art technology they employ. In contrast, developing countries tend to develop their own technologies and are less likely to obtain knowledge from abroad. Table 2 outlines the development of various technologies in Taiwan together with the introduction of foreign technologies, which could explain the high citation rate for Taiwanese patents.

Table 2. Knowledge flow related to Taiwanese biofuel patents (by sector)

\begin{tabular}{|c|c|c|c|c|c|c|c|c|c|c|c|c|c|c|c|c|c|}
\hline \multicolumn{4}{|c|}{ University } & \multicolumn{3}{|c|}{ PRI } & \multicolumn{3}{|c|}{ Individual } & \multicolumn{4}{|c|}{ Private sector } & State-owned enterprise & & \multicolumn{2}{|c|}{ foreign invest } \\
\hline Coting & $\mathrm{N}$ & Cited & N Citing & $\mathrm{N}$ & Cited & Citing & $\mathrm{N}$ & Cited & $\mathrm{N}$ & Citing & $\mathrm{N}$ & Cited & Citing & Cited & Citing & Cited & $\mathrm{N}$ \\
\hline$T W$ & $0(0 \%)$ & TW & $\mathrm{TW}$ & $0(0 \%)$ & $\mathrm{TW}$ & $28(79 \%) \mathrm{TW}$ & $0(0 \%)$ & $\mathrm{TW}$ & $x(0 \%)$ & $\mathrm{TW}$ & $0(0 \%)$ & $T W$ & $36(6.2 \%) \mathrm{CN}$ & $T W$ & $O(0 \%) \quad \mathrm{TW}$ & $23(5.6 \%) \mathrm{TW}$ & $\alpha 0 \%)$ \\
\hline $\mathrm{JP}$ & & 11 & SG & & $1 \mathrm{US}$ & $245 \mathrm{~GB}$ & & $6 \mathrm{USS}$ & & $55 \mathrm{~GB}$ & & $12 \mathrm{JJS}$ & 266 & USS & $15 \mathrm{US}$ & 159 US & 360 \\
\hline DE & & 2 & & & $\mathrm{DE}$ & $36 \mathrm{US}$ & & $2 \mathrm{DE}$ & & 8 & & $\mathbb{J P}$ & 79 & $\mathrm{FR}$ & $13 \mathrm{DE}$ & $99 \mathrm{FR}$ & 99 \\
\hline & & & & & IT & 13 & & $\mathrm{FR}$ & & 7 & & $C A$ & 52 & TT & $7 \mathrm{P}$ & $73 \mathbb{P}$ & 86 \\
\hline & & & & & SG & 12 & & $\mathrm{CA}$ & & 4 & & FI & 33 & $\mathrm{NL}$ & $6 \mathrm{CA}$ & $23 \mathrm{NL}$ & 35 \\
\hline & & & & & FR & 5 & & SE & & 1 & & DK & 30 & $\mathbb{P}$ & $6 \mathrm{FR}$ & $12 \mathrm{~GB}$ & 34 \\
\hline & & & & & AU & 5 & & $\mathrm{JP}$ & & 1 & & NL & 24 & $C A$ & $6 \mathrm{TT}$ & $9 \mathrm{DE}$ & 31 \\
\hline & & & & & MY & 2 & & AT & & 1 & & $\Gamma$ & 13 & & DK & 6ES & 6 \\
\hline & & & & & KR & 2 & & & & & & $D E$ & 13 & & $\mathrm{KR}$ & $3 \mathrm{ZA}$ & 3 \\
\hline & & & & & $\mathrm{JP}$ & 2 & & & & & & $\mathrm{CN}$ & 9 & & NL & 2SE & 3 \\
\hline & & & & & $\mathrm{HR}$ & 2 & & & & & & $\mathbb{N}$ & 8 & & $\mathrm{BE}$ & $2 \mathrm{KR}$ & 3 \\
\hline & & & & & & & & & & & & $\mathrm{CA}$ & 8 & & & TT & 3 \\
\hline & & & & & & & & & & & & $\mathrm{BG}$ & 7 & & & $\mathbb{N}$ & . \\
\hline & & & & & & & & & & & & FR & 6 & & & L & 1 \\
\hline & & & & & & & & & & & & $\mathrm{NZ}$ & 5 & & & & \\
\hline & & & & & & & & & & & & $\mathrm{KR}$ & 2 & & & & \\
\hline & & & & & & & & & & & & $G B$ & 2 & & & & \\
\hline Total & & 23 & & & 1 & 352 & & 8 & 8 & 7 & & 12 & 580 & & 61 & 411 & 665 \\
\hline
\end{tabular}

\section{Second Generation Biofuel Technology Developed in Taiwan}

\subsection{Bio-Hydrogen Technology}

Hydrogen energy has been attracting considerable attention from researchers. In 2011, the global market for hydrogen and hydrogen fuel-cells was approximately 1.08 billion USD (IEA, 2012). Bio-hydrogen provides the following benefits: (1) low cost and high production rate; (2) high efficiency and sustainable production; (3) clean burning (without pollution); (4) heat value per unit is approximately 2.5 times higher than that of methane 
and 3 times that of gasoline. Hydrogen is seen as a prime candidate to replace coal and oil in the future (Dunn, 2002; Kotay and Das, 2008). Taiwan has initiated research into biofuel technologies, such as bacteria filtering for hydrogen production, bio-reactor design, structural analysis of bacteria, and the integration of hydrogen energy systems. Feng Chia University (FCU) in Taichung City has succeeded in using sludge from a sewage treatment plant to provide bacteria for a fermentative hydrogen production facility capable of producing hydrogen at a rate of $360 \mathrm{~L} / \mathrm{L} / \mathrm{d}$ using simple molecular (sucrose) fermentation, and at a rate of $48 \mathrm{~L} / \mathrm{L} / \mathrm{d}$ using macromolecular (starch) fermentation. These are the highest hydrogen production rates in the world (Lai et al., 2011; Wu et al., 2006; Hawkes, Hussy, \& Dinsdale, 2007). This patented technology has already undergone transfer and may help promote the utilization of emerging alternative energy sources.

\subsection{Algae for Biotechnology Production Technology}

As an island, Taiwan is abundant in marine resources, including Botryococcus Braunii and Nitzschia Palea with oil volumes above $40 \%$ - ideal raw materials for the production of bio-diesel. Microalgae are fast-growing, with high photosynthesis efficiency, and do not require large areas of lands for cultivation. Taiwanese researchers have patented a number of technologies related to the mass production of algae and the decomposition of micro-organisms for the production of bio-diesel and bio-ethanol (TWI284018, TWI291327). Other researchers have employed gene transgenic technology to increase the volume of oil in micro-algae, as well as techniques to use the algae bodies remaining after the oil extraction process as additives for animal feed (Wu, 2007). Taiwan has also finished the development, design and construction of a modular outdoor photosynthetic reaction system providing up to 1500 liters for cultivation and a maximum production rate of $32 \mathrm{gm}$ in just 2 days. In addition, a pattern of downstream manufacturing has been established for the annual production of 1,000 tons of algae to demonstrate the feasibility of mass production and help to develop less power-consuming micro-algae-filtering and multi-task micro-algae oil extraction technologies. Placing algae-breeding farms in the vicinity of coastal power plants could help to reduce carbon dioxide emissions by 40 to 80 tons per year. The Industry Development Bureau (2012) estimated that approximately 10 thousand hectares of algae-breeding farms could be placed in Taiwan, with a total production of 0.15 to 0.3 million tons of natural oil per year, making possible the production of 0.15 to 0.3 million kiloliters of bio-diesel.

\section{Conclusions}

This study employed patent information to analyze the innovation capability and technological interdependence of biofuel technologies in Taiwan. Our results revealed three major discoveries. (1) In Taiwan, most patented biofuel technologies are owned by FDI in the chemical industry, such as BP, Celanese and BASF. Bio-fuel technology is highly dependent on chemical technology, chemical compounds and their preparation, and batteries for the direct conversion of chemicals into electrical energy. (2) Domestic Taiwanese patent assignees focus on second generation biofuel technologies, such as the treatment of waste, micro-organisms, and bio-hydrogen. Our findings indicate that the adoption of micro-organic technologies for the isolation and filtering of bacteria and the adoption of transgenic technologies for waste treatment are ideal candidates for the production of alternative energy and should be the focus of $\mathrm{R} \& \mathrm{D}$ efforts in the future. Using the same analytical methods, Hu and Phillips discovered that Chinese patents for bio-fuel are generally related to human necessities (A23L, C12N), and initiated by Chinese universities rather than public research institutes (Hu \& Phillips, 2011). (3) Finally, our results demonstrate the dependence of the biofuel industry on technology from a wide range of disciplines. The knowledge creation processes of biofuel technologies heavily depend on the utilization of related technologies in other fields through knowledge generation, diffusion, combination and extraction. Technological advances in the areas of electronics, biology, and environmental protection may serve as a cornerstone for the development of second generation biofuel technology.

Biofuels used to be developed primarily by refineries or petrochemical companies, which transferred this technology to countries to which they had access. The Taiwanese biofuel market remains relatively uncompetitive; therefore, domestic companies and owned the biofuel patents such as TSMC and Nan-ya lack the incentive to invest in R \& D in this area. However, this paper analysis biofuel related technologies evolved and interact with other technology fields. By utilizing endogenous technology capability embedded in the national innovation capacity. The findings provide the resource-lack countries like Taiwan, through trajectory of inventorying the relevance of related industrial technologies may serves as effective linkage and catalyst in problem-solving to help select alternative potential energy technologies to stimulate the growth of emerging industries and developed their own advantage industrial technologies and building innovation capabilities. For the prospect of biofuel implementation in Taiwan will be moderated by energy policy priorities and develop of endogenous second generation technology capabilities in the biotechnology and environmental technology fields. 


\section{References}

Abernathy, W. J., \& Clark, K. B. (1993). Innovation: mapping the winds of creative destruction. Research Policy, 22(2), 102. http://dx.doi.org/10.1016/0048-7333(93)90040-O

Chen, F. L., \& Chang, Y. L. (2007). Renewable energy in Taiwan: Its developing status and strategy. Energy, 32, 1634-1646. http://dx.doi.org/10.1016/j.energy.2006.12.007

Christensen, C. M. (1997). The Innovator's Dilemma: When New Technologies Cause Great Firms to Fail. Cambridge, MA: Harvard Business School Press.

Cohen, W. M., \& Levinthal, D. A. (1989). Innovation and learning: the two faces of R \& D. Economic Journal, 99, 569-596. http://dx.doi.org/10.2307/2233763

Dahlin, K., \& Behrens, D. M. (2005). When is an invention really radical? Defining and measuring technological radicalness. Research Policy, 34, 717-737. http://dx.doi.org/10.1016/j.respol.2005.03.009

Dodgson, M., Mathews, J. A., Kastelle, T., \& Hu, M. C. (2008). The evolving nature of Taiwan's national innovation system: the case of biotechnology innovation networks. Research Policy, 37(3), 430-445. http://dx.doi.org/10.1016/j.respol.2007.12.005

Dunn, S. (2002). Hydrogen futures: toward a sustainable energy system. International Journal of Hydrogen Energy, 27, 235-264. http://dx.doi.org/10.1016/S0360-3199(01)00131-8

Ernst, H. (2003). Patent information for strategic technology management. World Patent Information, 25, 233-242. http://dx.doi.org/10.1016/S0172-2190(03)00077-2

Freeman, C., \& Soete, L. (1997). The Economics of Industrial Innovation (3rd ed.). Pinter, London and Washington.

Fung, M. K., \& Chow, W. W. (2003). Identification of technological structures using patent statistics. Economic Innovation and New Technology, 12(4), 293-313. http://dx.doi.org/10.1080/1043859022000000826

Geels, F. W. (2005). Processes and patterns in transitions and system innovations: refining the co-evolutionary multi-level perspective. Technological Forecasting \& Social Change, 72(6), 681-696. http://dx.doi.org/10.1016/j.techfore.2004.08.014

Harhof, D., Schererc, F. M., \& Vopel, K. (2003). Citations, family size, opposition and the value of patent rights. Research Policy, 32(8), 1343-1363. http://dx.doi.org/10.1016/S0048-7333(02)00124-5

Hawkes, F. R., Hussy, I., Dinsdale, G., \& Hawkes, R. D. L. ( 2007). Continuous dark fermentative hydrogen production by mesophilic microflora: Principles and progress. International Journal of Hydrogen Energy, 32(2), 172-184. http://dx.doi.org/10.1016/j.ijhydene.2006.08.014

$\mathrm{Hu}$, M. C. (2008). Knowledge flows and innovation capability: patenting trajectory of Taiwan's thin film transistor-liquid crystal display industry. Technological Forecasting and Social Change, 75(9), 1423-1438. http://dx.doi.org/10.1016/j.techfore.2008.04.005

$\mathrm{Hu}$, M. C., \& Phillips, F. (2011). Technology evolution and interdependence in China's emerging biofuel industry. Technological Forecasting and Social Change, 78(7), 1130-1146. http://dx.doi.org/10.1016/j.techfore.2011.02.013

International Energy Agency. (2012). Key world energy statistics. Retrieved from http:/www.iea.org/publications/freepublications/publication/kwes.pdf

Industry development Bureau. (2012). White book of energy economic industry in Taiwan. Printed by Ministry of Economics.

Jasjit, S. (2004). Multinational firms and knowledge diffusion: evidence using patent citation data. Harvard Business School.

Kortum, S. (1997). Research, patenting, and technological change. Econometrica, 65(6), 1389-1419. http://dx.doi.org/10.2307/2171741

Kotay, S., \& Das, D. (2008). Biohydrogen as a renewable energy resource-prospects and potentials. International Journal of Hydrogen Energy, 29, 258-263.

Lai,W. H., Chen, H. Y., Chang, F. Y., Wu, C. C., Lin, C. Y., \& Huang, S. R. (2011). Market and patent analysis of commercializing biohydrogen technology. International Journal of Hydrogen Energy, 36(21), 14049-14058. http://dx.doi.org/10.1016/j.ijhydene.2011.03.155 
Schablitzky, H. W., Lichtscheidl, J., Rauch, R., \& Hofbauer, H. (2012). Investigations on Hydrotreating of Fischer Tropsch-Biowaxes for Generation of Bio-Products from Lignocellulosic Biomass. Modern Applied Science, 6(4), 28-37. http://dx.doi.org/10.5539/mas.v6n4p28

Stolpe, M. (2002). Determinants of knowledge diffusion as evidenced in patent data: the case of liquid crystal display technology. Research Policy, 31, 1181-1198. http://dx.doi.org/10.1016/S0048-7333(01)00192-5

Wade, R. (2004). Governing the market: economic theory and the role of government in East Asian industrialization (2nd ed.). Princeton university press, Princeton.

Wang, T., He, J., \& Tang, J. (2008). Research of Quality Improvement and Quality Innovation Based on Knowledge Fermenting Model. Modern Applied Science, 2(1), 38-42.

Webb, C., Dernis, H., Harhoff, D., \& Hoisl, K. (2005). Analysing European and international patent citations: a set of EPO patent database building blocks, OECD Science Technology and Industry Working Papers.

Wu, S. Y., Hung, C. H., Lin, C. N., Chen, H. W., Lee, A. S., \& Chang, J. S. (2006). Fermentative hydrogen production and bacterial community structure in huge-rate anaerobic bioreactors containing silicone-immobilized and self-flocculated sludge.Biotechnology and bioengineering, 93(5), 934-946. http://dx.doi.org/10.1002/bit.20800

Wu, P. F. (2007). The feasibility of biodiesel production from native algae in Taiwan. Master Thesis, Feng Chia University.

\section{Appendix A-1.}

The 95 identified biofuel related international patent classifications (4-digit)

\begin{tabular}{|c|c|c|c|c|c|c|c|c|c|}
\hline IPCs & Definitions & IPCs & Definitions & IPCs & Definitions & IPCs & Definitions & IPCs & Definitions \\
\hline A01H 1 & $\begin{array}{l}\text { Processes for } \\
\text { modifying } \\
\text { genotypes }\end{array}$ & B01J 8 & $\begin{array}{l}\text { Chemical or physical } \\
\text { processes in general, } \\
\text { conducted in the } \\
\text { presence of fluids } \\
\text { and solid particles; } \\
\text { apparatus for such } \\
\text { processes }\end{array}$ & C07C 55 & $\begin{array}{l}\text { Saturated } \\
\text { compounds } \\
\text { having more than } \\
\text { one carboxyl } \\
\text { group bound to } \\
\text { acyclic carbon } \\
\text { atoms }\end{array}$ & $\mathrm{C} 08 \mathrm{~F} 8$ & $\begin{array}{l}\text { Chemical } \\
\text { modification } \\
\text { by } \\
\text { after-treatment }\end{array}$ & $\mathrm{C} 12 \mathrm{~N} 15$ & $\begin{array}{l}\text { Mutation } \\
\text { genetic } \\
\text { engineering; DNA } \\
\text { or RNA } \\
\text { concerning genetic } \\
\text { engineering, } \\
\text { vectors. }\end{array}$ \\
\hline A01H 5 & $\begin{array}{l}\text { Flowering plants, } \\
\text { i.e. angiosperms }\end{array}$ & B02B 1 & $\begin{array}{lll}\text { Preparing } & \text { grain for } \\
\text { milling } & \text { or like } \\
\text { processes } & & \end{array}$ & C07C 67 & $\begin{array}{l}\text { Preparation of } \\
\text { carboxylic acid } \\
\text { esters }\end{array}$ & C08L 99 & $\begin{array}{l}\text { Compositions } \\
\text { of natural } \\
\text { macromolecula } \\
\mathrm{r} \text { compounds or } \\
\text { of derivatives } \\
\text { thereof not } \\
\text { provided for in } \\
\text { groups }\end{array}$ & $\mathrm{C} 12 \mathrm{P} 1$ & $\begin{array}{l}\text { Preparation of } \\
\text { compounds } \\
\text { compositions, not } \\
\text { provided for in } \\
\text { groups }\end{array}$ \\
\hline А01H 9 & $\begin{array}{l}\text { Pteridophytes, e.g. } \\
\text { ferns, } \\
\text { club-mosses, and } \\
\text { horse-tails }\end{array}$ & В02B 5 & $\begin{array}{l}\text { Grain treatment not } \\
\text { otherwise provided } \\
\text { for }\end{array}$ & C07C 69 & $\begin{array}{l}\text { Esters of } \\
\text { carboxylic acids; } \\
\text { Esters of carbonic } \\
\text { or haloformic } \\
\text { acids }\end{array}$ & C09F 7 & $\begin{array}{l}\text { Chemical } \\
\text { modification of } \\
\text { drying oils }\end{array}$ & $\mathrm{C} 12 \mathrm{P} 3$ & $\begin{array}{l}\text { Preparation of } \\
\text { elements or } \\
\text { inorganic } \\
\text { compounds except } \\
\text { carbon dioxide }\end{array}$ \\
\hline A01H 13 & Algae & B02C 9 & $\begin{array}{l}\text { Other milling } \\
\text { methods or mills } \\
\text { specially adapted for } \\
\text { grain }\end{array}$ & C07D 211 & $\begin{array}{l}\text { Heterocyclic } \\
\text { compounds } \\
\text { containing } \\
\text { hydrogenated } \\
\text { pyridine rings, } \\
\text { not condensed } \\
\text { with other rings }\end{array}$ & C09J 103 & $\begin{array}{l}\text { Adhesives } \\
\text { based on } \\
\text { starch, amylose } \\
\text { or amylopectin } \\
\text { o }\end{array}$ & C12P 5 & $\begin{array}{l}\text { Preparation of } \\
\text { hydrocarbons }\end{array}$ \\
\hline $\mathrm{A} 23 \mathrm{C} 9$ & $\begin{array}{l}\text { Milk preparations; } \\
\text { milk powder or } \\
\text { milk powder } \\
\text { preparations }\end{array}$ & B02C 19 & $\begin{array}{l}\text { Other disintegrating } \\
\text { devices or methods }\end{array}$ & C07D 307 & $\begin{array}{l}\text { Heterocyclic } \\
\text { compounds } \\
\text { containing } \\
\text { five-membered } \\
\text { rings having one } \\
\text { oxygen atom as } \\
\text { the only ring } \\
\text { hetero atom }\end{array}$ & C10L 1 & $\begin{array}{l}\text { Liquid } \\
\text { carbonaceous } \\
\text { fuels }\end{array}$ & C12P 7 & $\begin{array}{l}\text { Preparation of } \\
\text { oxygen-containing } \\
\text { organic } \\
\text { compounds }\end{array}$ \\
\hline A23D 9 & $\begin{array}{l}\text { Other edible oils } \\
\text { or fats, e.g. }\end{array}$ & B09B 3 & $\begin{array}{l}\text { Destroying } \\
\text { waste }\end{array}$ & C07D 311 & $\begin{array}{l}\text { Heterocyclic } \\
\text { compounds }\end{array}$ & C10L 5 & Solid fuels & C12P 13 & $\begin{array}{l}\text { Preparation of } \\
\text { nitrogen-containin }\end{array}$ \\
\hline
\end{tabular}




\begin{tabular}{|c|c|c|c|c|c|c|c|c|c|}
\hline IPCs & Definitions & IPCs & Definitions & IPCs & Definitions & IPCs & Definitions & IPCs & Definitions \\
\hline & $\begin{array}{l}\text { shortenings and } \\
\text { cooking oils }\end{array}$ & & $\begin{array}{l}\text { transforming solid } \\
\text { waste }\end{array}$ & & $\begin{array}{l}\text { containing } \\
\text { six-membered } \\
\text { rings having one } \\
\text { oxygen atom as } \\
\text { the only hetero } \\
\text { atom, condensed } \\
\text { with other rings }\end{array}$ & & & & $\begin{array}{l}\text { g organic } \\
\text { compounds }\end{array}$ \\
\hline A23J 1 & $\begin{array}{l}\text { Obtaining protein } \\
\text { compositions for } \\
\text { foodstuffs; bulk } \\
\text { opening of eggs } \\
\text { and separation of } \\
\text { yolks from whites }\end{array}$ & B30B 11 & $\begin{array}{l}\text { Presses specially } \\
\text { adapted for forming } \\
\text { shaped articles from } \\
\text { material in } \\
\text { particulate or plastic } \\
\text { state. }\end{array}$ & $\mathrm{C} 07 \mathrm{~F} 9$ & $\begin{array}{l}\text { Compounds } \\
\text { containing } \\
\text { elements of the } \\
\text { 5th Group of the } \\
\text { Periodic System }\end{array}$ & C11B 1 & $\begin{array}{l}\text { Production of } \\
\text { fats or fatty } \\
\text { oils from raw } \\
\text { materials }\end{array}$ & C12P 19 & $\begin{array}{l}\text { Preparation } \\
\text { compounds } \\
\text { containing } \\
\text { saccharide radicals }\end{array}$ \\
\hline A23L 1 & $\begin{array}{lr}\text { Foods } & \text { or } \\
\text { foodstuffs; } & \text { their } \\
\text { preparation } & \text { or } \\
\text { treatment } & \end{array}$ & C01B 31 & $\begin{array}{l}\text { Carbon; compounds } \\
\text { thereof }\end{array}$ & C07G 17 & $\begin{array}{l}\text { compounds of } \\
\text { unknown } \\
\text { constitution }\end{array}$ & C11B 3 & $\begin{array}{l}\text { Refining fats or } \\
\text { fatty oils }\end{array}$ & C12P 21 & $\begin{array}{ll}\text { Preparation } & \text { of } \\
\text { peptides } & \text { or } \\
\text { proteins } & \end{array}$ \\
\hline A23K 1 & $\begin{array}{l}\text { Animal } \\
\text { feeding-stuffs }\end{array}$ & $\mathrm{C} 02 \mathrm{~F} 9$ & $\begin{array}{l}\text { Multistage treatment } \\
\text { of water, waste } \\
\text { water, or sewage }\end{array}$ & $\mathrm{C} 07 \mathrm{H} 15$ & $\begin{array}{l}\text { Compounds } \\
\text { containing } \\
\text { hydrocarbon or } \\
\text { substituted } \\
\text { hydrocarbon } \\
\text { radicals directly } \\
\text { attached to hetero } \\
\text { atoms of } \\
\text { saccharide } \\
\text { radicals }\end{array}$ & $\mathrm{C} 11 \mathrm{C} 1$ & $\begin{array}{l}\text { Preparation of } \\
\text { fatty acids } \\
\text { from fats, fatty } \\
\text { oils, or waxes; } \\
\text { refining the } \\
\text { fatty acids }\end{array}$ & C12P 39 & $\begin{array}{l}\text { Processes } \\
\text { involving } \\
\text { micro-organisms } \\
\text { of different genera } \\
\text { in the same } \\
\text { process, } \\
\text { simultaneously }\end{array}$ \\
\hline A61K 48 & $\begin{array}{l}\text { Medicinal } \\
\text { preparations } \\
\text { containing genetic } \\
\text { material which is } \\
\text { inserted into cells } \\
\text { of the living body } \\
\text { to treat genetic } \\
\text { diseases; GENE } \\
\text { therapy }\end{array}$ & $\mathrm{C} 02 \mathrm{~F} 11$ & $\begin{array}{l}\text { Treatment of sludge; } \\
\text { devices therefore }\end{array}$ & C07H 19 & $\begin{array}{l}\text { Compounds } \\
\text { containing a } \\
\text { hetero } \\
\text { sharing }\end{array}$ & $\mathrm{C} 11 \mathrm{C} 3$ & $\begin{array}{l}\text { Fats, oils, or } \\
\text { fatty acids by } \\
\text { chemical } \\
\text { modification of } \\
\text { fats, oils, or } \\
\text { fatty acids } \\
\text { obtained } \\
\text { therefrom }\end{array}$ & C12Q 1 & $\begin{array}{l}\text { Measuring or } \\
\text { testing processes } \\
\text { involving enzymes }\end{array}$ \\
\hline B01D 1 & Evaporating & C07B 61 & $\begin{array}{l}\text { General methods of } \\
\text { organic chemistry }\end{array}$ & С07H 21 & $\begin{array}{l}\text { Compounds } \\
\text { containing two or } \\
\text { more } \\
\text { mononucleotide } \\
\text { units }\end{array}$ & $\mathrm{C} 12 \mathrm{C} 11$ & $\begin{array}{l}\text { Fermentation } \\
\text { processes for } \\
\text { beer }\end{array}$ & C12R 1 & $\begin{array}{l}\text { Processes using } \\
\text { micro-organisms }\end{array}$ \\
\hline B01D 3 & $\begin{array}{l}\text { Distillation or } \\
\text { related exchange } \\
\text { processes in } \\
\text { which liquids are } \\
\text { contacted with } \\
\text { gaseous media }\end{array}$ & $\mathrm{C} 07 \mathrm{C} 1$ & 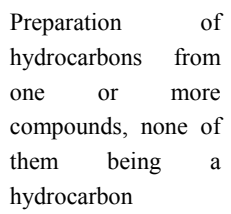 & $\mathrm{C} 07 \mathrm{~K} 1$ & $\begin{array}{l}\text { General methods } \\
\text { for the } \\
\text { preparation of } \\
\text { peptides }\end{array}$ & $\mathrm{C} 12 \mathrm{G} 1$ & $\begin{array}{l}\text { Preparation of } \\
\text { wine or } \\
\text { sparkling wine }\end{array}$ & C13D 1 & $\begin{array}{l}\text { Production } \\
\text { sugar, i.e. sucrose } \\
\text { and juices }\end{array}$ \\
\hline B01D 5 & $\begin{array}{l}\text { Condensation of } \\
\text { vapors; recovering } \\
\text { volatile solvents } \\
\text { by condensation }\end{array}$ & $\mathrm{C} 07 \mathrm{C} 2$ & $\begin{array}{l}\begin{array}{l}\text { Preparation of } \\
\text { hydrocarbons from } \\
\text { hydrocarbons } \\
\text { containing a smaller } \\
\text { number of carbon } \\
\text { atoms }\end{array}\end{array}$ & $\mathrm{C} 07 \mathrm{~K} 4$ & $\begin{array}{l}\text { Peptides having } \\
\text { up to } 20 \text { amino } \\
\text { acids in an } \\
\text { undefined or only } \\
\text { partially defined } \\
\text { sequence; } \\
\text { derivatives } \\
\text { thereof }\end{array}$ & C12G 3 & $\begin{array}{l}\text { Preparation of } \\
\text { other alcoholic } \\
\text { beverages }\end{array}$ & C13K 1 & Glucose \\
\hline B01D 13 & $\begin{array}{l}\text { Processes of } \\
\text { separation } \\
\text { employing } \\
\text { semi-permeable } \\
\text { membranes }\end{array}$ & $\mathrm{C} 07 \mathrm{C} 6$ & 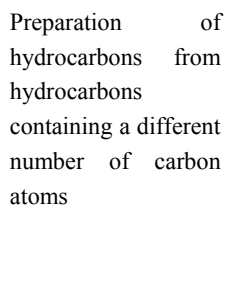 & $\mathrm{C} 07 \mathrm{~K} 14$ & $\begin{array}{l}\text { Peptides having } \\
\text { more than } 20 \\
\text { amino acids; } \\
\text { gastrins; } \\
\text { somatostatins; } \\
\text { melanotropins; } \\
\text { and derivatives } \\
\text { thereof }\end{array}$ & C12L 11 & Cellar tools & C25B 1 & $\begin{array}{l}\text { Electrolytic } \\
\text { production } \\
\text { inorganic } \\
\text { compounds } \\
\text { non-metals }\end{array}$ \\
\hline B01D 17 & Separation & $\mathrm{C} 07 \mathrm{C} 27$ & Processes involving & C07K 17 & Carrier-bound or & C12M 1 & Apparatus for & D21C 3 & Pulping \\
\hline
\end{tabular}




\begin{tabular}{|c|c|c|c|c|c|c|c|c|c|}
\hline IPCs & Definitions & IPCs & Definitions & IPCs & Definitions & IPCs & Definitions & IPCs & Definitions \\
\hline & $\begin{array}{l}\text { liquids, not } \\
\text { provided for } \\
\text { elsewhere, e.g. by } \\
\text { thermal diffusion }\end{array}$ & & $\begin{array}{l}\text { the simultaneous } \\
\text { production of more } \\
\text { than one class of } \\
\text { oxygen-containing } \\
\text { compounds }\end{array}$ & & $\begin{array}{l}\text { immobilized } \\
\text { peptides }\end{array}$ & & $\begin{array}{l}\text { enzymology or } \\
\text { microbiology }\end{array}$ & & $\begin{array}{l}\text { cellulose-containin } \\
\text { g materials }\end{array}$ \\
\hline B01D 61 & $\begin{array}{l}\text { Processes } \\
\text { specially adapted } \\
\text { for manufacturing } \\
\text { semi-permeable } \\
\text { membranes for } \\
\text { separation } \\
\text { processes }\end{array}$ & C07C 29 & $\begin{array}{l}\text { Preparation of } \\
\text { compounds having } \\
\text { hydroxy or O-metal } \\
\text { groups bound to a } \\
\text { carbon atom not } \\
\text { belonging to a } \\
\text { six-membered } \\
\text { aromatic ring }\end{array}$ & C08B 11 & $\begin{array}{l}\text { Preparation of } \\
\text { cellulose ethers }\end{array}$ & $\mathrm{C} 12 \mathrm{~N} 1$ & $\begin{array}{l}\text { Micro-organis } \\
\text { ms, e.g. } \\
\text { protozoa; and } \\
\text { compositions } \\
\text { thereof }\end{array}$ & G01N 33 & $\begin{array}{l}\text { Investigating or } \\
\text { analyzing materials } \\
\text { by specific } \\
\text { methods not } \\
\text { covered by the } \\
\text { preceding groups }\end{array}$ \\
\hline B01D 71 & $\begin{array}{l}\text { Semi-permeable } \\
\text { membranes for } \\
\text { separation } \\
\text { processes } \\
\text { apparatus } \\
\text { characterized by } \\
\text { the material }\end{array}$ & C07C 31 & $\begin{array}{l}\text { Saturated compounds } \\
\text { having hydroxy or } \\
\text { O-metal groups } \\
\text { bound to acyclic } \\
\text { carbon atoms }\end{array}$ & C08B 30 & $\begin{array}{l}\text { Preparation of } \\
\text { starch, degraded } \\
\text { or } \\
\text { non-chemically } \\
\text { modified starch, } \\
\text { amylose, or } \\
\text { amylopectin }\end{array}$ & C12N 5 & $\begin{array}{l}\text { Undifferentiate } \\
\mathrm{d} \text { human, } \\
\text { animal or plant } \\
\text { cells, e.g. cell } \\
\text { lines; tissues; } \\
\text { cultivation or } \\
\text { maintenance } \\
\text { thereof }\end{array}$ & 更 & $\begin{array}{l}\text { Fuel cells; } \\
\text { manufacture } \\
\text { thereof }\end{array}$ \\
\hline B01F 17 & $\begin{array}{l}\text { Use of substances } \\
\text { as emulsifying, } \\
\text { wetting, } \\
\text { dispersing or } \\
\text { foam-producing } \\
\text { agents }\end{array}$ & C07C 51 & $\begin{array}{l}\text { Preparation of } \\
\text { carboxylic acids or } \\
\text { their salts, halides or } \\
\text { anhydrides }\end{array}$ & C08B 31 & $\begin{array}{ll}\text { Preparation } & \text { of } \\
\text { derivatives } & \text { of } \\
\text { starch } & \end{array}$ & $\mathrm{C} 12 \mathrm{~N} 9$ & $\begin{array}{l}\text { Enzymes; } \\
\text { proenzymes; } \\
\text { and } \\
\text { compositions } \\
\text { thereof }\end{array}$ & F26B 25 & $\begin{array}{l}\text { Details of general } \\
\text { application not } \\
\text { covered by group }\end{array}$ \\
\hline B01J 3 & $\begin{array}{l}\text { Processes of } \\
\text { utilising } \\
\text { sub-atmospheric } \\
\text { or } \\
\text { super-atmospheric } \\
\text { pressure to effect } \\
\text { chemical or } \\
\text { physical change of } \\
\text { matter }\end{array}$ & C07C 53 & $\begin{array}{l}\text { Saturated compounds } \\
\text { having only one } \\
\text { carboxyl group } \\
\text { bound to an acyclic } \\
\text { carbon atom or } \\
\text { hydrogen }\end{array}$ & C08B 37 & $\begin{array}{l}\text { Preparation of } \\
\text { polysaccharides } \\
\text { not provided for } \\
\text { in groups }\end{array}$ & $\mathrm{C} 12 \mathrm{~N} 11$ & $\begin{array}{l}\text { Carrier-bound } \\
\text { or immobilized } \\
\text { enzymes; } \\
\text { carrier-bound } \\
\text { or immobilized } \\
\text { microbial cells }\end{array}$ & & \\
\hline
\end{tabular}

\section{Appendix A-2.}

\section{The 90 identified biofuel related keywords}

\begin{tabular}{lll}
\hline Identified keywords & & \\
\hline Acetaldehyde & Chrysosporium & Pre-treatment \\
Acetic acid & Cinnamic acid & Polysaccharide \\
Acyltransferase & Cyanobacteria & Separations \\
Adsorption & Diacylglycerol & Fractionation \\
Alcohol tolerance & E. coli & Glycerol \\
Algae & Enterococci & GMO \\
Alpha-amylase & Enzymatic cleavage & Greenhouse gas \\
Amino acids & Enzymatic hydrolysis & Hydrogen \\
Anaerobic digestion & Estherification & L-lysine \\
Arabinose & Esthers & Lignin \\
Aspergillus & Ethylene & Lignocellulosic material \\
Biocatalyst & Extraction & Maize \\
Bioethanol & Ethanol & Methanol \\
Biodiesel & Expansion & Microorganisms \\
Biogas & Fats & Novel enzymes \\
Biological conversion & Fatty acid & Olefin \\
Biomass & Fermentation & Polynucleotide \\
Biopolymer & Fermentable sugars & Pyruvate \\
Biosynthetic pathway & Filamentous fungi & Pyruvic acid \\
& & \\
& &
\end{tabular}




\begin{tabular}{lll}
\hline Identified keywords & & \\
\hline Biotechnology & Gelatinization & Recombinant DNA \\
Beta-glucanase & Gaseous byproduct & Recombinant organism \\
Butanol & Hydrocarbon & Recovery \\
Corn & Hydrolysis & Second-generation biofuels \\
Cellulosic ethanol & Isolation & Starch \\
Cellulosic material & Lactic acid & Sugar beet \\
Cellulose & Methane & Sweet potato \\
Catalyst mixing & Polypeptides & Syngas \\
Carbon dioxide & Polymerization & Triglycerides \\
Cellulases & Polyesters & Vegetable oil \\
Cellulolytic & Purification & Waste \\
\hline
\end{tabular}

Source: Biofuels, Bioproducts, and Biorefining, http://www.biofpr.com

\section{Copyrights}

Copyright for this article is retained by the author(s), with first publication rights granted to the journal.

This is an open-access article distributed under the terms and conditions of the Creative Commons Attribution license (http://creativecommons.org/licenses/by/3.0/). 